\title{
The current situation in Soviet psychiatry regarding political abuses
}

\author{
Testimony before a Hearing of the US Commission on Security and Cooperation in \\ Europe, 12 July 1989
}

\section{Peter Reddaway*}

The current situation in Soviet psychiatry needs a surrealist of Kafka's skill to describe it. On the one hand, an increasing range of Soviet journals have, since last November, been forthrightly saying what Soviet dissidents and Western observers have said for 20 years. This is that politically motivated abuse of psychiatry has taken place in the USSR on a large scale for decades, causing enormous human suffering. Second, some of these journals point out that abuses, though much reduced in scale, continue to occur today.

On the other hand, the leaders of Soviet psychiatry, and also, on occasion, the politicians who ultimately employ them, put forward a completely different picture. Either they say or imply that no such abuse has ever occurred, or - a slight variant they say that a few accidental mistakes occurred in the past as a result of psychiatrists being overly cautious and producing "hyperdiagnoses", but that now such mistakes cannot occur, thanks to new legislation and administrative reforms. The leadership as a whole also continues three long-established practices-manipulating foreign psychiatric organisations and delegations, thwarting victims of abuse who seek psychiatric "rehabilitation" or justice through the courts, and trying to discredit domestic critics of these abuses.

The worlds occupied by these two groups are profoundly different from each other. The US psychiatric delegation which visited the USSR earlier this year experienced the difference when it found itself shunting back and forth between them. In the first world, which includes liberal journalists, unofficial psychiatrists, and dissidents, dialogue was easy and uninhibited. But when we stepped through the

* Mr Reddaway is Professor of Political Science and International Affairs at the George Washington University. $\mathrm{He}$ is the author (with Dr Sidney Bloch) of Russia's Political Hospitals (US title: Psychiatric Terror), Gollancz, London 1977, and Soviet Psychiatric Abuse: The Shadow over World Psychiatry, West view Press, Boulder, Colorado, 1985. He is an Honorary Consultant to the American Psychiatric Association. He has also written widely on Soviet politics. looking-glass into the second world, which had organised our official programme and made sure that it included only approved doctors, dialogue was either impossible or so tortuous as to be exhausting and usually unproductive. Since basic facts could not be acknowledged by the Soviet side, conversation lacked common points of reference and could proceed, if at all, only through circumlocutions and hints.

Why does such a dualistic situation exist? For the simple reason that, since early 1987, the long-standing leaders of Soviet psychiatry have been fighting to preserve their power in the epoch of perestroika, or restructuring. Perestroika is a comprehensive programme which aims to bring efficiency and integrity to the economy, society, and politics in the USSR. In most fields, reform is well underway, and many if not all of the old leaders have been retired, disgraced, or even jailed. In psychiatry, even though perestroika has been needed for reasons of foreign as well as domestic policy, the leaders are still hanging on. The reason why the Foreign Ministry has pressed for reform is that it has been working for nearly three years to improve the human rights image of the USSR in the West, and psychiatric abuse has been one of the ugliest warts on that image.

However, the psychiatric leaders know that if they were to allow serious reform, it would soon sweep them away. They have long presided over a branch of medicine which, in addition to harbouring violators of the Hippocratic Oath led by themselves, is also inefficient, scientifically backward and even obscurantist, expensive to the state, and probably at least as corrupt as most of Soviet medicine.

For this reason, reform in Soviet psychiatry has, to date, been limited in declared intent and even more limited in practice. As regards the system of political abuse, its most visible manifestation - hospitalised dissidents whose cases are known in the West - has now been largely removed by the convenient device of suddenly declaring them cured and releasing them. But the system's infrastructure remains in place, and we also know from new information as it arrives, that some dissidents previously unknown abroad remain 
interned, and also that new internments are sporadically occurring. Just as important, if a repressive leader were to replace Gorbachev, and/or if a crackdown on reformers and dissidents of the type recently seen in China were to take place-developments which could occur in the next few years - then the system could start "processing" large numbers of victims without difficulty. The US psychiatric delegation gained insight into this system thanks to receiving considerably more access than previous delegations to patients, records, and institutions, but this will not make it inoperative.

\section{Recent Soviet press articles on psychiatric abuse}

Since last summer a dozen or so articles in the Soviet press $^{1}$ have written frankly or very frankly about problems of abuse. Two weeks ago, on 28 June 1989, a classic case was described in the government paper Izvestiya. Nothing was previously known in the West about the victim, Yu I. Sobolev, a former director of a timber yard, even though he has been hospitalised three times for dissent, and his psychiatric internments have totalled a year and a half. Although diagnosed as psychotic with a "depressive-paranoid syndrome", he was found by the hospital, and by the reporter, to be normal. The origins of the third internment were described with unusual candour by a deputy police chief in the Ulyanovsk region on the middle Volga: three weeks before the elections to the Congress of People's Deputies last March, "I was phoned by the First Secretary of the Nikolayevka District Party Committee, V. A. Panasenko, who said that at a candidate's election meeting Sobolev had been putting forward some sort of undesirable ideas. He said that Sobolev must be taken out of circulation. I phoned the psychiatrist V. F. Kamalov and explained the situation. He said he'd write an order for hospitalisation."

Now, the reporter writes, Dr Kamalov "admits that he consigned to compulsory treatment in a mental hospital a man who was not on the psychiatric register, and whom he had never even set eyes on." His self-serving comment is: "What's one to do, if one's given an order?"

The answer to this is that many Soviet psychiatrists faced with the same situation have, without doing anything heroic, found ways of avoiding complicity in a professional and juridical crime.

The most significant aspect of the case, however, is the casual, routine way in which the hospitalisation

'Among those not discussed in this testimony are articles in Literaturnaya gazeta (31 May 1989), Znamya (No. 7, 1988), Uchitelskaya gazeta (19 November 1988), and Meditsinskaya gazeta (21 May 1989). took place-at a time when officials of the Ministries of Health and Foreign Affairs had long been telling foreigners in private that such practices had stopped, and also, coincidentally, when the US delegation was in the country. Observers already knew this was not true, because news of a score of new internments over the last year had reached the West. However, the victims in these cases had soon been discharged, and had not been hospitalised through the criminal commitment process. It was therefore possible to believe that these hospitalisations might be local aberrations which would soon come to an end. The Sobolev case, however, tends to confirm my suspicion that whatever secret instructions have been issued by Moscow to local authorities probably tell them (a) to avoid criminal commitments in political cases; and (b) what to do if news of a local case of civil or administrative commitment leaks out, namely, to get the individual released. In other words, the motivation of such instructions is probably not to eliminate new cases of political abuse altogether, but to prevent its continuing, more infrequent use from causing problems for the USSR's foreign policy.

A somewhat similar case is that of the Ukrainian dissident Anatoly Ilchenko, whom the US delegation examined in March and found to be in no need of hospitalisation. He was immediately released. The only difference in this case was that the local authorities in the Ukraine were more careless. They had overlooked the fact that Ilchenko's name, though not well known, had in fact been registered earlier in the West, in connection with his previous internment for dissident activities.

Another recent article in the Soviet press (by Leonid Zagalsky, Literaturnaya gazeta, 28 June 1989 ) is notable for its wide range and also for being the first to call for the resignation of three long-standing top executives of the system of political abuse Drs Georgy Morozov, Marat Vartanyan, and Alexander Churkin. Dr Churkin, the Chief Psychiatrist of the Ministry of Health, played a prominent role in the negotiations for, and conduct of, the recent US psychiatric delegation. In May of this year he was invited - by a group of American psychiatrists who did not trouble to look into his credentials - to take part as an honoured guest in the annual convention of the American Psychiatric Association in San Francisco. I shall say more about him and his colleagues below.

Zagalsky's article starts by examining the primitive material conditions, the dirt and demoralised atmosphere, of Soviet mental hospitals, including that of Moscow's Serbsky Institute for General and Forensic Psychiatry. He describes how he accompanied an earlier American group to this institute, and how they were carefully kept away from the depressing sight of the wards - a sight which 
was "not suitable for weak-nerved Americans." Only hardened Soviets could "endure such a spectacle".

Zagalsky then discusses the history of how Soviet psychiatry "started to serve politics". Early on, as in the well-known case of the biologist Zhores Medvedev, it was sometimes possible for established intellectuals to get a victim released quickly. But this soon became difficult, as victims were locked up for "long years" and "those who interceded for them faced the threat of serious punishment".

Thus the foreign criticism which led in 1983 to the USSR's resignation from the World Psychiatric Association (WPA) was, in Zagalsky's view, fully justified. He seems to doubt whether the Soviet application to be readmitted will be approved at the WPA's congress in Athens this October ("as the saying goes, we'll wait and see"). Certainly the thrust of his article suggests a belief that Soviet psychiatry has not yet earned readmission.

In this connection he looks at the records of Churkin, Morozov, and Vartanyan, who hold in their hands "all the reins" of Soviet psychiatry. Churkin has been Chief Psychiatrist of the Ministry of Health for more than a decade-a term which makes clear "what role he played in dissident cases ... all these years." Zagalsky quotes Churkin's views on the recent visit by American psychiatrists. When asked what would happen if the latter examined hospitalised dissidents and diagnosed them differently, Churkin truculently replied: "They have a right to their opinion. But it will not change the subsequent treatment of the patient."

Churkin, Morozov and Vartanyan are servile officials, Zagalsky goes on, "people of the past." A vast quantity of facts about the abuse of psychiatry and its use for political purposes testifies incontrovertibly to the guilt of the leaders of this branch of medicine. It was with their connivance that healthy people were sent to mental hospitals, their reputations and whole lives ineradicably damaged."

"If", Zagalsky continues, "even one human life has been wrecked through one's own fault, one should resign. This is what people do in societies claiming to be civilised, if their actions have been discredited in the view of public opinion." In this case, however, "no one has resigned." The claim is that "psychiatry has changed so much that now no one will ever be put in a mental hospital without strict criteria being met." Again, Zagalsky's comment is sceptical: "We'll wait and see." $\mathrm{He}$ ends his article by recounting several cases of the Sobolev type, and with an analysis of how the mental health legislation of 1988 has been undermined by Ministry of Health directives. The result, in his opinion, is that "as in the past" no one is safe from arbitrary hospitalisation and excruciating treatment with sulphazine.
The dishonesty and untrustworthiness of the leaders of Soviet psychiatry

Zagalsky rightly implies that no radical change can occur in Soviet psychiatry as long as its present leaders remain in power. Apart from other factors, their deception and manipulation of Western psychiatrists over many years have shown them to be unscrupulous. This has been documented at length, particularly in two books by Sidney Bloch and myself, and has not been challenged.

Evidence of this untrustworthiness also came to light during the US delegation's recent trip to the USSR. Particularly striking to me was the physical ejection from our hotel in Kazan of two young psychiatrists, who had just started telling members of our group what things had been concealed from us during our visit to the Kazan Special Psychiatric Hospital (SPH). They were ejected by the Deputy Director of the SPH, Dr Nail Idrisov. Also striking were the statements by a number of patients in the Kazan and Chernyakhovsk SPHs that they had been warned they would be punished if they spoke to us negatively about the SPHs. All this simply reflected the stance of the psychiatric leaders in Moscow, who had been forced by the Kremlin to go along with our visit, but were still determined to manipulate as far as possible the outcome.

More recently, the deviousness and furtiveness which prevented frank, straightforward discussion of the issues with the official psychiatrists whom we met, showed up in the new USSR Supreme Soviet, when Minister of Health Evgeny Chazov was asked whether psychiatric abuse had been ended (TASS, 10 July 1989). Chazov avoided a direct reply, but said that the 1988 legislation provided a guarantee against abuses, that the SPHs had been transferred from the Ministry of Internal Affairs (MVD) to the Ministry of Health, and that recent psychiatric delegations from abroad had not been able to name a single person currently held in mental hospitals because of his beliefs.

The truculent disingenuousness of this reply did not surprise me, since Chazov is closely associated with Vartanyan, has worked in the Ministry for nearly 20 years, and almost certainly believes that if the lid is finally blown off Soviet psychiatry, he will risk disgrace along with Vartanyan and the others. But it is still worth noting the deviousness of his reply. First, the 1988 legislation and related Ministry directives have been shown by Soviet lawyers, as well as by Zagalsky and foreign commentators, to be seriously defective. Second, the transfer of the SPHs is only a very partial one. It allows the MVD to continue to have a strong influence over the SPHs, since it still employs-directly or indirectly-the key personnel in them. Third, in referring to foreign psychiatric delegations Chazov deceptively omitted 
to mention, first, that our delegation had, in March, found no reason why five hospitalised dissidents whom it examined should be confined; second, that we had found other patients in hospitals we visited whose cases were at least partly political or religious, and who appeared, if only on short acquaintance, not to need confinement; and third, that medically unjustified commitments of dissidents were still occurring, such as that of Sobolev, which had just been reported by the main organ of the government to which Chazov himself belonged. And finally, Chazov's reply did not admit that the political abuse to which the questioner referred had ever occurred.

Even on purely factual matters, health officials are often untrustworthy. It recently came to light, for example, that Churkin's claim of early 1988 that there were then 5.6 million citizens on the psychiatric register is not correct. According to the journal Ogonek, the State Statistics Committee gives a figure of 10.4 million for the same date.

\section{How much change has occurred in the area of forensic psychiatry, and what prospects exist for further change?}

My view, as a result of our trip, is that a timid start has been made to reform, but it has been imposed on a resistant, hostile, and defensive $\mathrm{MoH}$ by politicians who have been able at times to mobilise certain journalists and lawyers in their support. The prospects for further change seem uncertain and, as long as Vartanyan, G. Morozov, Chazov, Nikolai Zharikov, and Churkin remain the key figures, extremely limited. All the knowledgeable independent witnesses known to me (mostly Soviets, including a couple in the higher ranks) regard the forensic psychiatric system as being in bad shape, and our visit provided much evidence to the same effect.
There is no sense of any strong momentum to the change, or enthusiasm for it-except, within the severe limits of what is possible at the grass-roots level. There is no policy of removing unsuitable staff; only a little of the critical and advocacy material collected by journalists and lawyers is currently getting permission to be printed; the $\mathrm{MoH}$ is clearly playing an important blocking role, and when it fails to block something, it either ignores it or reacts hostilely; there is no confidence that the $\mathrm{MoH}$ will increase current funding levels for PHs.

In sum, perhaps $10 \%$ of what is needed has been done, but no break-through has yet occurred, and currently there is no strong momentum which might produce one. The Establishment is just holding the line and fighting hard - mostly with success. In my view, though, if the individuals listed were to be removed or transferred to professorships, this would be the key development which could easily lead to real reform (perestroika) taking place in Soviet psychiatry, as has already occurred in other spheres of Soviet life. In those circumstances, I believe that political abuse would soon be ended and authoritatively condemned, and at least some safeguards against its re-emergence might be developed.

The worst contribution we could make to the reform of Soviet psychiatry would be diplomatically to soften our criticisms of it. The best contribution is to be frank and direct, just as we are about the shortcomings of American psychiatry.

\section{Independent Soviet recommendations regarding the WPA}

Finally, dissidents like Alexander Podrabinek have for the last year taken the view that Soviet readmission to the WPA would be premature. This view has now been argued by the Kiev psychiatrist Semyon Gluzman in a letter to Western colleagues.

I concur with Dr Gluzman's views. 